\title{
Faktor-Faktor Sukses Wirausaha Wanita di Sumatera Barat
}

\author{
Indah Maya Sari ${ }^{1}$ \\ 1 Jurusan Ilmu Ekonomi (Fakultas Ekonomi, Universitas Andalas)
}

\begin{abstract}
Overpopulation in an area will affect labor market conditions, which is characterized by an increase in the number of unemployed in highly populated areas. Entrepreneurship is one solution that can help the economic condition. The entrepreneur can solve excess labor or help reduce unemployment. The high number of women in West Sumatra each year is a huge potential, especially in entrepreneurship. Success in entrepreneurship is the goal of every woman in entrepreneurship. This research aims to see how the factors of marital status, experience, and use of Information and Communication Technology (ICT) such as the use of the telephone and the internet influence women's success in entrepreneurship. This study uses primary data "raw data" Susenas 2019. The results show that marital status, telephone use and internet use and experience influence women's success in entrepreneurship in West Sumatra.
\end{abstract}

\begin{abstract}
Abstrak
Overpopulasi di suatu daerah akan mempengaruhi kondisi pasar kerja yang ditandai dengan meningkatnya jumlah pengangguran di daerah berpenduduk tinggi. Kewirausahaan merupakan salah satu solusi yang dapat membantu kondisi perekonomian tersebut. Wirausaha dapat menyelesaikan kelebihan tenaga kerja atau membantu mengurangi jumlah pengangguran. Tingginya jumlah penduduk wanita di Sumatera Barat setiap tahun merupakan potensi yang sangat besar, khususnya dalam berwirausaha. Sukses berwirausaha merupakan tujuan setiap wanita dalam berwirausaha. Penelitian ini bertujuan untuk melihat bagaimana faktor status perkawinan, pengalaman, dan penggunaan Teknologi Informasi dan Komunikasi (TIK) seperti penggunaan telepon, dan internet dalam mempengaruhi keberhasilan wanita dalam berwirausaha. Penelitian ini menggunakan data primer yaitu "raw data" Susenas tahun 2019. Hasil penelitian menunjukkan bahwa status perkawinan, penggunaan telepon dan penggunaan internet serta pengalaman berpengaruh terhadap keberhasilan wanita dalam berwirausaha di Sumatera Barat.
\end{abstract}

Keywords: Women Entrepreneurship, Education, ICT

Corresponding author: Indah Maya Sari (indahmayasari@eb.unand.ac.id)

\section{Pendahuluan}

Distribusi penduduk yang tidak merata dan laju pertumbuhan penduduk yang tinggi dapat menimbulkan berbagai permasalahan. Menumpuknya jumlah penduduk di daerah tertentu misalnya dapat mempengaruhi kondisi pasar kerja yang berujung pada peningkatan jumlah pengangguran karena tidak seimbangnya jumlah lapangan kerja yang tersedia dengan jumlah pencari kerja. Selanjutnya, laju 
pertumbuhan yang tinggi tentunya akan membuat besarnya laju pertumbuhan ekonomi tidak berarti. Kondisi distribusi dan laju penduduk tersebut bermuara pada meningkatnya pengangguran.

Jika mengurangi penduduk dan melakukan pemerataan populasi merupakan solusi yang cukup rumit, maka dari sisi sebaliknya upaya penumbuhan lapangan kerja perlu diinisiasi secara maksimal. Pilihan ada pada upaya pemerintah dalam menciptakan lapangan kerja baru, atau dukungan pemerintah pada upaya masyarakat untuk menciptakan lapangan kerja sendiri bagi dirinya dan masyarakat lainnya merupakan solusi positif meningkatkan laju pertumbuhan ekonomi dan mengurangi pengangguran. Upaya kewiraan yang heroic dari masyarakat dalam membantu negara menumbuhkan perekonomian dan mengatasi pengangguran itu disebut denan istilah wirausaha.

Wirausaha merupakan salah satu solusi yang banyak membantu kondisi perekonomian suatu wilayah, dengan wirausaha dapat menanggulangi kelebihan tenaga kerja, sekaligus membantu dalam menekan jumlah pengangguran karena juga dapat menyerap tenaga kerja yang ada. Banyaknya jumlah penduduk wanita di Sumatera Barat setiap tahunnya merupakan suatu potensi yang sangat besar jika dimanfaatkan, khususnya dalam berwirausaha. Menurut Verheul, dkk (2006) dalam Idris (2009) mengatakan bahwa, selain memberikan kontribusi terhadap pertumbuhan ekonomi, wirausaha wanita juga menambah keragaman dan pilihan dalam lingkungan berbisnis. Tambunan (2009) menganalisis data sekunder dari 14 negara-negara di Asia, ditemukan bahwa perkembangan wirausaha wanita dibatasi terutama oleh nilai-nilai budaya dan sosial yang diperlihatkan dari kurangnya pendidikan dan kesempatan berkarir. Akibatnya wanita Asia biasanya hanya terlibat dalam usaha kecil, dengan penguasaan teknologi yang rendah sehingga didalam menjalankan usaha tidak memerlukan terlalu banyak modal dan keterampilan.

Partisipasi wanita dalam sektor ekonomi disini dapat kita lihat yaitu dengan keberanian wanita untuk menumbuhkan potensi dirinya dengan membuka usaha atau berwirausaha sesuai dengan keahlian, kerajinan serta pengalaman mereka untuk mencari nafkah dan meningkatkan status sosial dalam masyarakat sekaligus menambah pendapatan. Rachbini (2002) Menyatakan bahwa masalah kewirausahaan merupakan persoalan paling penting di dalam perekonomian suatu bangsa yang sedang membangun, karena kemajuan atau kemunduran ekonomi sangat ditentukan oleh keberadaan dan peran wirausaha, karena wirausaha mempunyai peranan yang penting dan krusial, baik sebagai gap filter atau input complementer. Apabila terjadi kesenjangan antara peluang yang ada, wirausaha berperan sebagai gap filter yang datang untuk menyambungnya. Apabila ada kekosongan untuk memberi masukan bagi gagasan yang harus dilaksanakan karena ada potensi pasar maka wirausaha datang sebagai input complementer. Menurut Alma (2003) Jumlah wirausahaan disuatu negara tidak perlu banyak, tetapi peranannya akan mewarnai seluruh proses modernisasi ekonomi dan sosial di dalam suatu masyarakat. Perserikatan Bangsa - bangsa (PBB) menyatakan bahwa peran wirausaha yang krusial dan kritis, serta suatu Negara akan mampu membangun apabila memiliki wirausahaan sebanyak $2 \%$ dari jumlah 
penduduknya. Jika syarat ini dipenuhi, perekonomian bangsa tersebut hampir dipastikan akan mengalami kemajuan yang berarti. Sehingga menurut Rachbini (2002) kelompok kecil wirausaha ini kemudian diartikulasikan sebagai kelompok determinan yang menentukan masa depan ekonomi suatu bangsa. Berdasarkan penjabaran tersebut penelitian ini bertujuan untuk melihat dan membahas lebih lanjut mengenai faktor-faktor apa saja yang mempengaruhi tingginya patisipasi wanita dalam berwirausaha di Sumatera Barat, serta menganalisis faktor-faktor yang mempengaruhi kesuksesan wirausaha wanita di Sumatera Barat.

\section{Literatur Review dan Pengembangan Hipotesis}

\section{Status Perkawinan}

Menurut Creevey (1996) diantara banyak latar belakang sosial dan budaya yang mempengaruhi keberadaan wirausaha wanita adalah terutama agama, tingkat pendidikan formal dan keahlian, umur, etnis dan kebiasaan, status perkawinan, dan lokasi geografis. Femida, Meenaz, dan Shree (2000) juga berpendapat bahwa faktor keyakinan, budaya, kelas sosial, pendidikan, dan latar belakang keluarga memainkan peranan penting yang mempengaruhi wirausaha wanita. Kajian mengenai berbagai variabel sosial ekonomi, termasuk pendidikan, pengalaman kerja, pendapatan, dan status perkawinan dan keluarga, untuk menentukan pengaruh pada wanita dalam berusaha. Faktor-faktor yang berpengaruh terhadap partisipasi wanita dalam dunia kerja, dimana rendahnya tingkat partisipasi kerja wanita oleh Arundarti (1993) dipengaruhi oleh: Faktor sosial seperti hambatan budaya, hambatan psikologi, keluarga serta agama. Faktor lainya yaitu faktor demografi yang meliputi tingginya tingkat pendidikan, status perkawinan, tingkat fertilitas mortalitas, dan tingkat pendidikan penduduk.

\section{Pengalaman}

Menurut Staw (1991) usia bisa terkait dengan keberhasilan bila dihubungkan dengan lamanya seseorang menjadi wirausaha. Dengan asumsi bahwa usia kronologis seseorang terkait dengan enterpreneurial age (lamanya seseorang menjadi wirausaha), ini berarti dengan bertambahnya usia seorang wirausaha maka semakin banyak pengalaman dibidang usahanya. Dengan demikian bertambahnya pengalaman ketika usia seseorang bertambah maka usia memang terkait dengan keberhasilan. Menurut Raduan, Naresh, dan Yen (2006), Tingkat pendidikan, pengalaman kerja (experience) dan mempunyai orang tua yang memiliki bisinis sendiri, memiliki hubungan yang positif dengan keberhasilan mereka dalam berwirausaha. Cooper (1985) juga menyatakan bahwa faktor-faktor seperti pengalaman atau latar belakang pekerjaan pengusaha, anggota keluarga, ilmu pengetahuan, dan keterampilan, adalah beberapa motif yang mengarah pada keberhasilan kewirausahaan. Pengalaman adalah pendidik yang paling baik, tetapi hanya jika kita bisa belajar dari pengalaman. Sesuai menurut Ronstadt (1988) dan Vesper (1980) dalam Wardatulaina (2011) pengalaman pada usaha sebelumnya bagi pengusaha merupakan kontribusi untuk mencapai kesuksesan. 
Hasil penelitian yang dilakukan oleh National Center for enterpreneural Research (dalam Mahmuddin, 2010) berhasil mengidentifikasi 26 perilaku perusahaan-perusahaan potensial yang berkembang di dunia yang menunjang kesuksesannya. Hasil penelitian tersebut menemukan tiga faktor yang berperan dalam kesuksesan wirausahawan, yaitu: kepribadian, pengalaman dan pembimbing. Peneliti meyakini bahwha faktor pengalaman sehari-hari (experience) dan kecakapan menjadi kunci keberhasilan dalam berwirausaha.

\section{Teknologi, Informasi dan Komunikasi (TIK)}

Munculnya teknologi dan internet telah membawa banyak perubahan pada cara menjalankan bisinis pada saat sekarang ini. Hubungan antara keterampilan teknologi dan pengembangan perusahaan khususnya kepada pengusaha sangat penting. Menurut Ndubisi dan Kahraman (2006), pentingnya TIK (Teknologi, Informasi dan Komunikasi) bagi wanita berwirausaha tidak dapat dipisahkan. Jika di masa lalu wanita harus berurusan dengan pria secara pribadi dan tatap muka, maka bisnis melalui Internet tidak lagi memerlukan aspek ini. Menurut Marlin dan Wright (2005) Faktor demografi seperti usia, jenis kelamin dan latar belakang yang tidak jelas, tidak tampak pada dunia maya, tidak seperti di dunia nyata. Oleh karena itu, transaksi bisnis "face to face" dapat diminimalkan dan wanita yang berwirausaha tidak akan dihadapkan dengan banyak diskriminasi. Menurut Millman dan Hartwick (1987), Komputerisasi dan otomatisasi kantor telah memberikan manfaat luar biasa untuk perusahaan seperti peningkatan kebebasan produktivitas untuk melakukan pekerjaan, meningkatkan kualitas kerja, dan menanamkan tanggung jawab lebih besar bagi si pengusaha.

Teknologi andalah pendorong bisnis yang memiliki dampak revolusioner pada perilaku yang sebenarnya dari bisnis. Ini memberikan kontribusi untuk mencapai produktivitas dan efisiensi bisnis yang diinginkan. Internet berfungsi sebagai contoh yang baik, apa yang digunakan untuk menjadi ketidakmungkinan dalam komunikasi global yang instant telah menjadi kenyataan dan merupakan kebutuhan mendesak bagi setiap bisnis untuk keberhasilan dan kelancaran usaha. Internet, termasuk ecommerce dan jaringan sosial, terus mengubah sifat peluang dan ancaman dalam berwirausaha. Ini mengubah siklus produksi, meningkatkan kecepatan distribusi, menciptakan produk dan layanan baru, perubahan skala ekonomi, dan mempermudah transaksi tanpa adanya batas. Singkatnya, Internet telah menjadi alat bisnis yang sangat diperlukan.

Teknologi telah meningkatkan layanan kepada pelanggan dan terhadap permintaan. Hal ini terutama berlaku pada teknologi komunikasi modern, karena data base online memungkinkan sejumlah besar informasi untuk dibagikan dengan mudah dan cepat antara perusahaan dan pelanggan mereka. Teknologi digital secara positif berdampak pada distribusi barang dan jasa melalui internet, meningkatkan kecepatan dan efisiensi dengan mana barang dan jasa yang diakses oleh konsumen dan kemudian disampaikan melalui bisnis online.

\section{Pendapatan}


Moeliono (1993:300) berpendapat bahwa keberhasilan identik dengan pendapatan, dengan begitu pendapatan merupakan salah satu kriteria bagi kegiatan usaha, yakni dapat dipergunakan untuk menilai keberhasilan usaha, atau dapat dikatakan keberhasilan usaha adalah suatu kenyataan persesuaian antara rencana dengan proses pelaksanaannya dan hasil yang dicapai. Robbins (1994:58) menyatakan keberhasilan usaha harus dinilai sehubungan dengan pencapaian tujuan, yang dimaksud pencapaian tujuan yang popular adalah menghasilkan laba. Akan tetapi kebutuhan usaha itu sifatnya relatif dan unsur memberikan dalam suatu kegiatan usaha juga sangat luas. Steers (1978:45) memberikan beberapa kriteria penting sebagai indikator keberhasilan usaha, yaitu: kemampuan menyesuaikan diri, produktifitas, kepuasan kerja, kemampuan mendapatkan laba dan pencarian sumber daya. Pendapat ini hampir serupa dengan yang dikemukakan Suranti (2006:46), menurutnya utuk mencapai keberhasilan usaha dapat dipakai suatu pendekatan yaitu meliputi pencapaian tujuan, pendekatan sistem, pendekatan konstituensi strategis, dan pendekatan nilai-nilai bersaing. Pendekatan pencapaian tujuan menyebutkan bahwa keberhasilan usaha harus dinilai sehubungan dengan pencapaian tujuan yaitu mendapatkan laba atau keuntungan yang merupakan selisih antara harga jual dengan biaya produksi.

\section{Lokasi}

Lingkungan tempat tinggal dibedakan menjadi dua, yaitu desa dan kota, menurut R. Bintarto (1977) desa yaitu perwujudan goegrafis yang ditimbulkan oleh unsur-unsur fisiografis, sosial, ekonomi, politik, kultur setempat dalam hubungan dan pengaruh timbal balik dengan daerah lain. Sedangkan kota adalah tempat tinggal penduduk yang heterogen dengan latar belakang budayanya yang berbeda ragam dan aktifitas penduduknya lebih bersifat ekonomis, materialistis dan mengarah pada sistem industri, atau kota adalah sistem jaringan kehidupan manusia yang ditandai oleh strata, sosial ekonomi, yang heterogen serta corak materialistis. Menurut Creevey (1996) diantara banyak latar belakang sosial dan budaya yang mempengaruhi keberadaan wirausaha wanita adalah terutama agama, tingkat pendidikan formal dan keahlian, umur, etnis dan kebiasaan, status perkawinan, dan lokasi geografis.

\section{Jumlah Tanggungan}

Keterlibatan kaum wanita disektor publik terutama sektor industri membawa dampak terhadap peranan wanita dalam kehidupan berkeluarga. Pada satu pihak wanita bekerja dapat berperan membantu ekonomi keluarga dan sebagai pencari nafkah utama dalam keluarga, disisi lain peranannya dalam urusan rumah tangga (domestik) menjadi berkurang karena lamanya waktu yang digunakan untuk aktivitas diluar rumah tangga (publik). Hal ini sesuai dengan pendapat Elfindri (2003) bahwa kebutuhan partisipasi wanita dibidang ekonomi sangat besar dalam era sekarang ini, terutama ditetapkannya model pembangunan yang berbasis kepada masyarakat. Alasan utama adalah karena wanita sesungguhnya memegang sejumlah fungsi sentral dalam keluarga, dan sekaligus merupakan sumber daya ekonomi yang tidak kalah penting dibandingkan dengan laki-laki. Keberadaan wanita dalam rumah tangga bukan 
sekedar pelengkap fungsi reproduksi saja tetapi banyak penelitian yang menyatakan bahwa wanita seringkali memberikan sumbangan yang besar bagi kelangsungan ekonomi dan kesejahteraan rumah tangga serta masyarakat. Alasan kedua adalah bahwa semakin lama wanita yang terdidik juga semakin meningkat jumlahnya bersamaan dengan semakin menurunnya jumlah anak yang dilahirkan, pada gilirannya waktu efektif untuk kegiatan yang berkaitan dengan home production akan menjadi berkurang.

\section{Pendidikan}

Ada pendapat yang menyatakan bahwa seorang wirausaha lebih memiliki streetsmart daripada booksmart, maksudnya adalah seorang wirausaha lebih mengutamakan untuk belajar dari pengalaman (streetsmart) dibandingkan dengan belajar dari buku dan pendidikan formal (booksmart). Pandangan ini masih perlu dibuktikan kebenarannya. Jika pendapat tersebut benar maka secara tidak langsung usaha-usaha yang dilakukan untuk mendorong lahirnya jiwa kewirausahaan lewat jalur pendidikan formal pada akhirnya akan sukar untuk berhasil. Terhadap pendangan di atas, Chruchill (1987) memberi sanggahan terhadap pendapat ini, menurutnya masalah pendidikan sangatlah penting bagi keberhasilan wirausaha. Bahkan dia mengatakan bahwa kegagalan pertama dari seorang wirausaha adalah karena dia lebih mengandalkan pengalaman daripada pendidikan. Namun dia juga tidak menganggap remeh arti pengalaman bagi seoranga wirausaha, baginya sumber kegagalan kedua adalah jika seorang wirausaha hanya bermodalkan pendidikan tapi miskin pengalamam lapangan. Oleh karena itu perpaduan antara pendidikan dan pengalaman adalah faktor utama yang menentukan keberhasilan wirausaha. Menurut Kim (dalam Meng \& Liang, 1996), Staw (1991), dan Katz (dalam Holt, 1992), setelah memasuki dunia kewirausahaan, mereka yang memiliki tingkat pendidikan yang lebih tinggi akan lebih berhasil dari pada mereka yang berpendidikan rendah, karena pendidikan di universitas mengenalkan mereka pada pengetahuan dan keterampilan manajerial modern, sehingga membuat mereka lebih sadar akan realitas dunia usaha saat ini dimana dengan demikian dapat membantu mereka dalam menggunakan kemampuan belajar mereka untuk mengelola bisnis (dalam Prihatin, 2004).

Tingkat pendidikan berpengaruh terhadap keinovatifan, kecepatan proses adopsi inovasi, dan perilaku seseorang, (Suparta 2005). Tingkat pendidikan yang semakin tinggi akan menambah wawasan dan pola berpikir yang kreatif serta diperlukan dalam keberhasilan menjalankan usaha.

\section{Teori Alokasi Waktu}

Untuk lebih memahami keterkaitan antara konsep teoritis mengenai partisipasi wanita dalam berwirausaha dan pola produktivitasnya maka mengacu kepada kerangka Teori Alokasi Waktu Becker (1965) yang diperluas oleh gronau (1977). Teori Alokasi Waktu Becker yang lebih dikenal dengan Teori Rumah Tangga Baru (New Home Economic Theory) membangun teorinya berdasarkan perilaku konsumen dalam ekonomi mikro dengan memperkenalkan rumah tangga atau keluarga sebagai unit analisisnya (Becker, 1965; Elfindri, 1989). Teori ini mengasumsikan bahwa utility rumah tangga tidak 
langsung dari konsumsi barang namun juga memaksimalkan utility dari suatu komodity $\mathrm{Z}$ dari kombinasi barang dan jasa (X) yang dikonsumsi selama periode tertentu. Hubungan ini dapat ditulis dengan:

$$
\mathrm{Z}=\mathrm{Z}(\mathrm{X}, \mathrm{T})
$$

Masing-masing komoditi $\mathrm{Z}$ dapat dibeli di pasar atau diproduksi sendiri di rumah, hingga totalnya menjadi:

$$
\mathrm{X}=\mathrm{Xm}+\mathrm{Xh}
$$

Hasil subsitusi persamaan 2 ke 1 menjadi fungsi utility:

$$
\mathrm{Z}=\mathrm{Z}(\mathrm{Xm}, \mathrm{Xh}, \mathrm{T})
$$

Komoditi yang dibeli dan diproduksi di rumah dipisahkan, dimana komoditi yang dihasilkan di rumah diproduksi dalam suatu periode waktu di rumah, sehingga:

$$
\mathrm{Xh}=\mathrm{f}(\mathrm{H})
$$

Konsumsi keluarga dimaksimalkan dengan batasan waktu dan anggaran, dimana pendapatan keluarga dan pengeluaran untuk konmsumsi $(\mathrm{Xm})$ tergantung pada income yang diperoleh di pasar tingkat upah individu (W) kali jumlah waktu yang digunakan untuk berkerja di pasar $(\mathrm{N})$ dan income yang berasal dari tenaga kerja lain dalam rumah tangga. Persamaan ini dapat ditulis secara matematis sebagai berikut:

$$
\mathrm{Xm}=\mathrm{WN}+\mathrm{V}
$$

Dalam hal ini waktu merupakan sumber daya yang penting, dengan batasan normal 24 jam sehari yang harus dialokasikan pada beberapa aktivitas seperti istirahat (Leisure), bekerja di rumah dan dipasar. Total persamaannya dapat ditulis sebagai berikut:

$$
\mathrm{T}=\mathrm{H}+\mathrm{N}+\mathrm{L}
$$

Tingkat konsumsi optimal suatu rumah tangga adalah saat marginal productivity dari bekerja di rumah sebanding dengan marginal rate dari substitusi antara barang dan konsumsi waktu.

Alokasi waktu keluarga mungkin pada aktivitas bekerja dan konsumsi. Kendala waktu adalah:

$$
\mathrm{Ti}=\mathrm{Tc}=\mathrm{T}-\mathrm{Tw}
$$

Dimana Tc adalah waktu untuk konsumsi yang jumlahnya sama dengan jumlah seluruh waktu yang tersedia. Becker menekankan bahwa waktu dapat dialokasikan secara efisien diantara aktivitas yang berbeda.

\section{Usia}

Reynolds et al. (2000) menemukan bahwa individu yang berusia 25 - 44 tahun adalah "most entrepreneurially" aktif. Menemukan dari studi lain di India oleh Sinha (1996) mengungkapkan bahwa pengusaha sukses relatif muda dalam usia. Dalam studi pada pengusaha Internet kafe di Indonesia, menurut Kristiansen, Furuholt, \& Wahid (2003) menemukan korelasi signifikan antara usia keberhasilan pengusaha dan bisnis, usia 25 tahun keatas atau lebih tua menjelaskan bahwa lebih berhasil daripada yang lebih muda. 


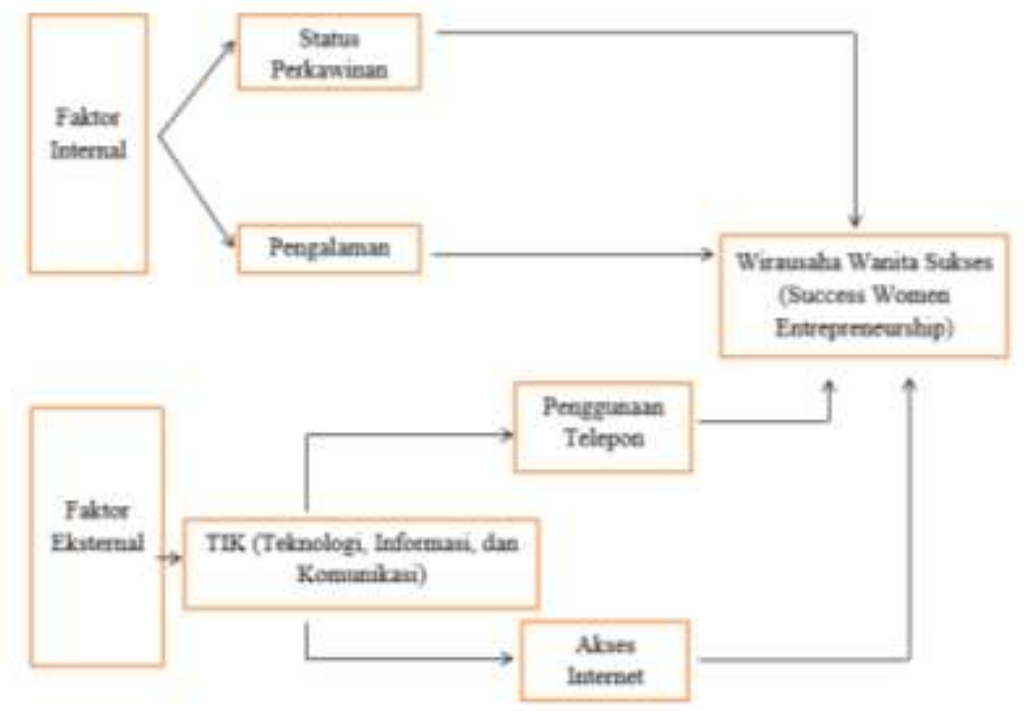

Gambar 1

Kerangka Analisis

Sumber: Prihatin (2004), dimodifikasi.

Berdasarkan gambar kerangka analisis diatas dapat disimpulkan bahwa penelitian ini dilakukan untuk mengetahui apa faktor-faktor yang mempengaruhi suksesnya wanita dalam berwirausaha di Sumatera Barat, dimana variabel-variabel yang mempengaruhi suksesnya wirausaha wanita yaitu: Status perkawinan, pengalaman, dan penguasaan TIK (Teknologi, Informasi dan Komunikasi).

\section{Metode Penelitian}

Penelitian ini menggunakan data primer dari data mentah (raw data) Survei Sosial Ekonomi Nasional (SUSENAS) Propinsi Sumatera Barat 2019 yang dilakukan oleh Badan Pusat Statistik (BPS) setiap tahun dalam upaya untuk mengumpulkan deskripsi rumah tangga dan populasi. Pendekatan yang digunakan adalah melalui Susenas rumah tangga dan penduduk, hal ini dilakukan dengan memilih sejumlah rumah tangga atau penduduk yang dilakukan secara random sampling.

\section{Metode Analisis data}

Sesuai dengan tujuan penelitian yang ingin dicapai, maka digunakan beberapa metode dalam menganalisis data, yaitu:

1. Metode Analisis Regresi Logistik (Logistic Regression Analysis) digunakan untuk mengetahui bagaimana tingkat partisipasi wanita dalam berwirausaha di Sumatera Barat.

2. Metode Analisis Regresi Berganda (Multiple Regression Analysis) digunakan sebagai tujuan untuk mengetahui faktor-faktor yang mempengaruhi kesuksesan wirausaha wanita di Sumatera Barat.

\section{Analisis Regresi Logistik (Logistic Regression Analysis)}


Metode regresi logistik digunakan karena kejadian pasti ada dan tidak pernah akan mencapai $100 \%$ atau sebaliknya $0 \%$. Ini ditujukan untuk melihat hubungan variable yang digunakan dalam menjelaskan partisipasi wanita berwirusaha di Sumatera Barat.

Dalam melakukan penelitian terhadap beberapa peubah sering diperoleh peubah-peubah yang bersifat kualitatif dan kuantitatif. Analisa regresi Logistik dipergunakan untuk melihat pengaruh variable independent terhadap variable dependent dimana variable dependentnya adalah biner, yaitu satu dan nol. Peubah respon yang berskala biner adalah peubah yang hanya menghasilkan dua kategori saja, misalnya $\mathrm{Y}=1$ menyatakan kejadian wanita yang masuk kategori berwirausaha, sedangkan $\mathrm{Y}=0$ menyatakan kejadian wanita yang tidak masuk kategori wanita berwirausaha. Untuk variable Independen (X) yang lebih dari satu disebut dengan Multiple Logistik Regression.

Model peluang regresi logistik dengan $\mathbf{p}$ faktor (peubah penjelas) adalah: (Hosmer dan Lemeshow, 1989 dalam Nachrowi, 2002).

$$
\pi(x)=\frac{\exp \left(\beta_{0}+\beta_{1} X_{1}+\beta_{2} X_{2}+\ldots \ldots \ldots \ldots+\beta_{p} X_{p}\right)}{1+\exp \left(\beta_{0}+\beta_{1} X_{1}+\beta_{2} X_{2}+\ldots \ldots \ldots \ldots .+\beta_{p} X_{p}\right)}
$$

Dimana $\pi(\mathrm{x})$ adalah peluang terjadinya $\mathrm{Y}=1$ atau dalam penelitian ini adalah peluang penduduk Sumatera Barat untuk berwirausaha, khususnya wanita.

Dengan melakukan transformasi logit dari $\pi(x)$, didapatkan persamaan yang lebih sederhana, yaitu:

$$
\begin{aligned}
& \pi(x) \\
& g(x)=\ln \\
& \{1-\pi(x)\} \\
& g(x)=\ln \pi(x)-\ln \{1-\pi(x)\}
\end{aligned}
$$

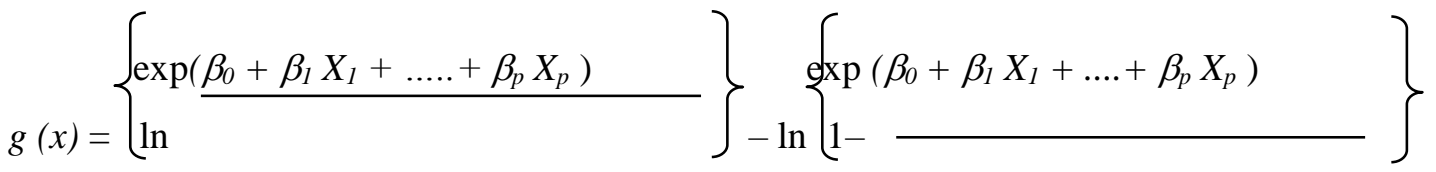

$$
\begin{aligned}
& 1+\exp \left(\beta_{0}+\beta_{1} X_{1}+\ldots .+\beta_{p} X_{p}\right) \quad 1+\exp \left(\beta_{0}+\beta_{1} X_{1}+\ldots+\beta_{p} X_{p}\right)
\end{aligned}
$$$$
g(x)=\ln \left\{\exp \left(\beta_{0}+\beta_{l} X_{1}+\ldots .+\beta_{p} X_{p}\right)\right\}-\ln \left\{1+\exp \left(\beta_{0}+\beta_{l} X_{l}+\ldots .+\beta_{p} X_{p}\right)\right\}-
$$

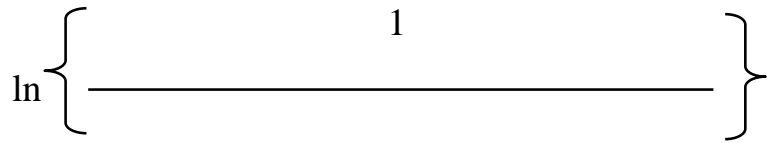




$$
\begin{aligned}
& \quad 1+\exp \left(\beta_{0}+\beta_{1} X_{1}+\beta_{2} X_{2}+\ldots .+\beta_{p} X_{p}\right) \\
& g(x)=\ln \beta_{0}+\beta_{1} X_{1}+\ldots .+\beta_{p} X_{p}-\ln 1 \\
& g(x)=\beta_{0}+\beta_{1} X_{1}+\ldots .+\beta_{p} X_{p}-0 \\
& g(x)=\beta_{0}+\beta_{1} X_{1}+\ldots .+\beta_{p} X_{p}
\end{aligned}
$$

Persamaan tersebut merupakan fungsi linier dalam parameter-parameternya.

Persamaan ini dijadikan model pengujian sebagai berikut:

$G(x)=\beta_{0}+\beta_{1} X_{1}+\beta_{2} X_{2}+\ldots .+\beta_{p} X_{p}$

$G(x)=\ln \{p /(1-p)\}$

$\ln \{p /(1-p)\}$ adalah Odds Ratio

Maka pada penelitian ini akan dipergunakan model yang dituliskan sebagai berikut:

$\ln \{p /(1-p)\}=\beta_{0}+\beta_{1} X_{1}+\beta_{2} X_{2}+\beta_{3} X_{3}+\beta_{4} X_{4}+\beta_{5} X_{5}+\beta_{6} X_{6}+\beta_{7} X_{7}+$

$$
\beta_{8} X_{8}+\beta_{9} X_{9}+\varepsilon
$$

atau

$\ln \{p /(1-p)\}=\beta_{0}+\beta_{1}$ Lokasi $+\beta_{2}$ Status $(1)+\beta_{3}$ Status $(2)+\beta_{4}$ Nart $+\beta_{5}$

$$
P d d k(1)+\beta_{6} P d d k(2)+\beta_{7} \text { Njamkerj+ } \beta_{8} \text { Age }(1)+\beta_{9} \text { Age }(2)+\varepsilon
$$

Dimana :

$$
\begin{array}{ll}
\mathrm{P} & =\text { Persentase dari wanita yang berwirausaha } \\
1-\mathrm{p} & =\text { Persentase dari yang lainnya } \\
\beta_{0} & =\text { Konstanta } \\
\beta_{l} & =\text { Koefisien regresi }\left(\beta_{l}, \beta_{2}, \ldots, \beta_{p}\right) \\
\mathrm{X}_{1} & =\text { Variable bebas }\left(X_{1}, X_{2}, \ldots, X_{p}\right) \\
\varepsilon & =\text { Error }
\end{array}
$$

\section{Tabel 1}




\section{Variable Dependent}

- Parisispasi Wanita Berwirausaha

1. Berwirausaha sendiri

0. Lainnya

\section{Variable Independent}

- Pendidikan

(PDDK1)

1. SD Kebawah- SD

0 . Lainnya

(PDDK2)

1. SLTA- SLTA Keatas

0 . Lainnya

- Banyak Tanggungan Keluarga

1. $>4$ orang

(NART1)

0 . Lainnya

- Usia

(AGE1)

1. $<30$ Tahun

0 . Lainnya

(AGE2)

1. 40 Tahun +

0 . Lainnya

- Status Perkawinan

1. Menikah

(STATUS1)

0 . Lainnya

1. Cerai

(STATUS2)

0 . Lainnya

- Jumlah Jam Kerja

1. > $34 \mathrm{Jam}$

(NJAMKERJA)

0 . Lainnya

- Lokasi

1. Kota

0 . Lainnya

\section{Pengujian Signifikansi Model dan Parameter}

1. Uji seluruh model (Uji G)

$\mathrm{H}_{0}: \beta_{l}=\beta_{2}=\ldots . .=\beta_{p}=0$

$\mathrm{H}_{1}$ : sekurang-kurangnya terdapat satu $\beta_{j} \neq 0$

Penguji dilakukan dengan statistik :

$\mathrm{G}=-2 \ln \left(\frac{\text { Likelihood }(\text { Model B) }}{\text { Likelihood }(\text { Model } \mathrm{A})}\right)$

Model B : model yang hanya terdiri dari konstanta saja

A : model yang hanya terdiri dari seluruh variable

$\mathrm{G}$ berdistribusikan Chi-Square dengan derajat bebas $\mathrm{p}$ atau $\mathrm{G} \sim X p^{2}$

$\mathrm{H}_{0}$ ditolak jika $\mathrm{G}>X^{2}{ }_{\alpha p} ; \alpha$ : tingkat siknifikansi, apabila $\mathrm{H}_{0}$ ditolak, maka model A signifikansi pada tingkat signifikansi $\alpha$. 
2. Uji Wald : uji signifikansi tiap-tiap parameter

$\mathrm{H}_{0}: \beta_{\mathrm{j}}=0$ untuk suatu $\mathrm{j}$ tertentu $; \mathrm{j}=0,1, \ldots, \mathrm{p}$

$\mathrm{H}_{1}: \beta_{j} \neq 0$

Penguji dilakukan dengan statistik :

$$
\mathrm{W}_{\mathrm{j}}=\left(\frac{\beta_{\mathrm{j}}}{\mathrm{SE}\left(\beta_{\mathrm{j}}\right)}\right)^{2} \quad ; j=0,1,2, \ldots, \mathrm{p}
$$

Statistik ini berdistribusi Chi-Square dengan derajat bebas 1 atau secara simbolis ditulis $\mathrm{W}_{\mathrm{j}}$ $X^{2}$.Dimana $\mathrm{H}_{0}$ ditolak jika $\mathrm{W}_{\mathrm{j}}>X_{\alpha 1}^{2}$; dengan $\alpha$ adalah tingkat signifikansi yang dipilih. $\mathrm{Bila} \mathrm{H}_{0}$ ditolak, artinya parameter tersebut signifikan secara statistik pada tingkat signifikansi $\alpha$.

Setelah persamaan model terbentuk maka langkah selanjutnya adalah menginterpretasikan koefisien-koefisien yang didapat.Dari model yang terbentuk diperoleh hasil yang penting untuk menginterprestasi model tersebut, yang biasa disebut odd ratio, yang merupakan perbandingan peluang antara dua kelompok individu dalam karakter yang berbeda.

Odd (risiko) didefenisikan sebagai $\{p /(1-p)\}$ dimana $\mathrm{p}$ menyatakan probabilitas sukses (terjadinya peristiwa $\mathrm{Y}=1)$ sedangkan $(1-\mathrm{p})$ menyatakan probabilitas gagal (terjadinya peristiwa $\mathrm{Y}=$ $0)$.

Dengan demikian odd ratio (perbandingan nilai odd atau risiko antara dua kelompok individu) yang dilambangkan $\psi$ dituliskan sebagai berikut:

$$
\psi=\left(\frac{\mathrm{P}^{(\mathrm{XA})} / 1-\mathrm{p}^{(\mathrm{XA})}}{\mathrm{P}^{(\mathrm{XB})} / \operatorname{lip}^{(\mathrm{XB})}}\right)
$$

Apabila variable bebas merupaka variable kategorik dengan dua kategori, katakan 1 dan 0 dengan kategori 0 sebagai refensi maka interprestasi koefisien pada variable ini adalah rasio dari nilai odd untuk kategori 1 terhadap nilai odds untuk kategori 0; dituliskan sebagai berikut :

$$
\psi=\left(\frac{\mathrm{P}^{\left(\mathrm{Xj}_{\mathrm{j}}\right)}}{1-\mathrm{p}^{\left(\mathrm{Xj}_{\mathrm{j}}\right)}} / \frac{\mathrm{P}^{\left(\mathrm{Xj}_{\mathrm{j}}=0\right)}}{1-\mathrm{p}^{\left(\mathrm{Xj}_{\mathrm{j}}=\right)}}\right)=\operatorname{Exp}\left(\beta_{j}\right)
$$

yaitu: peluang terjadinya peristiwa $\mathrm{Y}=1$ pada kategori $\mathrm{X}_{1}=1$ adalah sebesar $\operatorname{Exp}\left(\beta_{1}\right)$ kali peluang terjadi peristiwa $Y=1$ pada ketegori $X_{1}=0$. apabila variable bebas yang digunakan adalah variable 
kontinyu, maka interprestasi dari koefisien adalah setiap kenaikan $\mathrm{C}$ unit satuan pada variable bebas, akan mengakibatkan risiko terjadinya $\mathrm{Y}=1$ sebesar $\left(\mathrm{C} \beta_{j}\right)$ kali lebih besar

\section{Analisis Regresi Berganda (Multilpe Regression Analysis)}

Untuk mengetahui pengaruh dari variabel status perkawinan, pengalaman, dan TIK (Teknologi Informasi dan Komunikasi) sebagai faktor-faktor yang mempengaruhi suksesnya wirausaha wanita di Sumatera Barat, selanjutnya dihitung berdasarkan pada Analisis Regresi Berganda (Multiple Regression Analysis).

$$
\mathrm{Y}=\int\left(\mathrm{X}_{1}, \mathrm{X}_{2}, \mathrm{X}_{3}, \mathrm{X}_{4}\right)
$$

Dimana :

$$
\begin{aligned}
& \mathrm{Y}=\text { Pendapatan } \\
& \mathrm{X}_{1}=\text { Status Perkawinan (dummy Variable) } \\
& \mathrm{X}_{2}=\text { Pengalaman } \\
& \mathrm{X}_{3}=\text { TIK1 (penggunaan telepon) } \\
& \mathrm{X}_{4}=\text { TIK2 (penggunaan internet) }
\end{aligned}
$$

Untuk lebih menyederhanakan data akan diteliti selanjutnya persamaan (1) dapat dibentuk kedalam persamaan regresi berganda dan dapat ditulis sebagai berikut :

$\mathrm{Y}=\alpha+\beta_{1}$ stat $+\beta_{2}$ Exp $+\beta_{3} \mathrm{DTIK} 1+\beta_{4} \mathrm{DTIK} 2+\varepsilon$

Dimana :

$\alpha=$ Konstanta

$\beta_{1}, \beta_{2}, \beta_{3}$, dan $\beta_{4}=$ Koefisien regresi masing-masing variabel bebas

Stat $=$ Status Perkawinan

Dummy Variabel:

$1=$ jika responden sudah menikah

$0=$ jika responden belum menikah

Exp = Pengalaman (variabel numerik)

TIK1 = Teknologi, Informasi, Komunikasi pada penguasaan dan penggunaan telepon.Dummy

Variabel:

$1=$ jika responden mengguasai penggunaan telepon.

$0=$ jika responden tidak mengguasai penggunaan telepon.

TIK2 $=$ Teknologi, Informasi, Komunikasi pada penguasaan dan penggunaan internet

Dummy Variabel:

$1=$ jika responden mengguasai penggunaan telepon selular.

$0=$ jika responden tidak mengguasai penggunaan teleponselular.

$\varepsilon=$ Variabel penganggu (disturbance term)

\section{Hasil dan Analisis}




\section{Persamaan Regresi Logistik (Logistic Regression)}

Tingkat partisipasi wanita dalam berwirausaha di Sumatera Barat menggunakan data Susenas pada tahun 2019:

Tabel 2

Pertisipasi Wanita Dalam Berwirausaha dan Odd Ratio Susenas 2019

\begin{tabular}{|c|c|c|c|c|c|c|c|c|c|c|}
\hline Variable & Lokasi & Status1 & Status2 & Nart & Pddk1 & Pddk2 & NjamKerja & Age1 & Age2 & Const \\
\hline B & 0.201 & 0.824 & 1.903 & -0.055 & -0.355 & -0.788 & 0.062 & -0.493 & 0.095 & -1.126 \\
\hline Odd Ratio & 1.222 & 2.279 & 6.703 & 0.946 & 0.701 & 0.455 & 1.064 & 0.611 & 1.100 & 0.324 \\
\hline
\end{tabular}

Sumber : diolah dari Raw data Susenas 2019

Dari regresi logistik untuk wanita berwirausaha sendiri terdapat nilai overall sebesar $68.8 \%$, ini berarti secara keseluruhan hasil klasifikasi partisipasi wanita berwirausaha sendiri menunjukkan persentase ketepatan klasifikasi adalah sebesar $68.8 \%$.

Adapun hasil regresi logistik faktor sosial ekonomi yang mempengaruhi partisipasi wanita berwirausaha pada data Susenas 2019 dapat dilihat pada persamaan :

$\ln \{p /(1-p)\}=-1,126+0,201$ Lokasi $+0,824$ Status $(1)+1,903$ Status (2)

$$
\begin{aligned}
& -0,055 \text { Nart - 0,355 Pddk (1) - 0,788 Pddk (2) + 0,062 Njamkerj-0,493 Age (1)+ } \\
& \text { 0,095 Age (2) }
\end{aligned}
$$

Pada Susenas 2019 dengan nilai intersep yang sebesar $-1,126$ berarti pada saat semua variable independen yaitu lokasi, status perkawinan, banyak tanggungan, pendidikan, jumlah jam kerja, dan usia dianggap sama dengan nol, maka besarnya peluang partisipasi wanita berwirausaha sendiri dari beberapa karakterisrik tersebut adalah:

$$
\pi(x)=\frac{\mathrm{e}^{-1,126}}{1+\mathrm{e}^{-1,126}}=\frac{0,324327977}{1,324327977}=0,244900041
$$

Artinya : probabilitas bahwa partisipasi wanita dalam rumah tangga dengan karakteristik tersebut di atas akan ikut berwirausaha adalah sebesar 0.244 atau $24,4 \%$.

\section{Lokasi}

Slope untuk variable lokasi mempunyai parameter 0,201 artinya: peluang partisipasi wanita berwirausaha sendiri yang tinggal di daerah perkotaan lebih besar bila dibandingkan dengan peluang wanita berwirausaha sendiri di daerah pedesaan. Hal ini dapat dilihat pada data berikut:

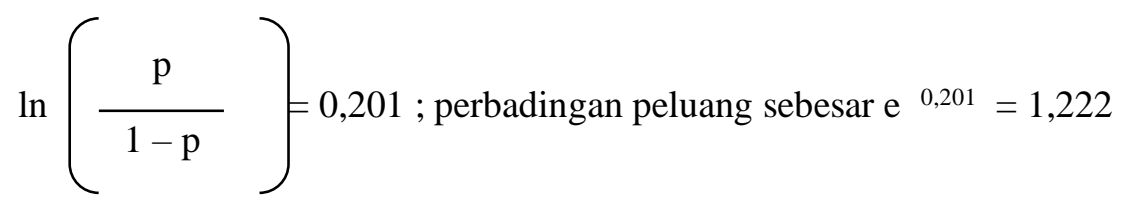

artinya; Peluang responden wanita yang tinggal di daerah perkotaan untuk berwirausaha sendiri adalah 1,222 kali bila dibandingkan dengan peluang responden wanita yang tinggal didaerah pedesaan. Dengan kata lain wanita yang tinggal di pedesaan mempunyai peluang yang lebih kecil untuk berwirausaha bila dibandingkan dengan wanita yang tinggal di daerah perkotaan. 


\section{Status Perkawinan}

Slope untuk variable status(1) mempunyai parameter 0,824 artinya: peluang partisipasi wanita berwirausaha sendiri yang berstatus menikah lebih besar dengan nilai Exp (B) sebesar 2,279 dapat diartikan peluang wanita menikah berwirausaha 2,279 kali bila lebih besar jika dibandingkan peluang wanita yang berstatus cerai dan belum menikah.

Hal yang sama juga terlihat pada variable status(2) dimana parameternya sebesar 1,903 artinya: peluang partisipasi wanita berwirausaha yang berstatus cerai lebih besar lagi dengan nilai Exp (B) sebesar 6,703 dan dapat diartikan peluang wanita berstatus cerai berwirausaha sendiri lebih tinggi, yaitu 6,703 kali bila dibandingkan dengan peluang wanita berwirausaha yang berstatus menikah dan belum menikah.

Munculnya kondisi ini pada data Susenas 2019 menjelaskan bahwa status perkawinan mempengaruhi wanita untuk ikut berwirausaha, dimana disini wanita yang statusnya cerai cenderung untuk ikut berpartisipasi dalam berwirausaha.

\section{Banyak Jumlah Anggota Rumah Tangga}

Pada data Susenas 2019 Slope untuk variable banyaknya jumlah anggota rumah tangga mempunyai parameter - 0,055 artinya: partisipasi wanita berwirausaha yang jumlah anggota rumah tangganya lebih dari 4 orang maka peluangnya lebih kecil dengan nilai Exp (B) sebesar 0,946 kali, dapat diartikan peluang wanita berwirausaha yang jumlah tanggungannya lebih dari 4 orang hanya 0,946 kali lebih kecil bila dibandingkan peluang wanita yang jumlah tanggungannya hanya 1 sampai 4 orang saja.

\section{Pendidikan}

Untuk variable pddk(1) pada data Susenas 2019 mempunyai parameter -0,355 artinya: peluang partisipasi wanita berwirausaha yang berpendidikan SD kebawah - SD lebih kecil dengan nilai Exp (B) sebesar 0,701 dimana dapat diartikan peluang wanita berpendidikan rendah untuk berwirausaha 0,701 kali lebih rendah bila dibandingkan peluang wanita yang berpendidikan menengah dan tinggi.

Begitu juga terlihat pada variable $\operatorname{pddk}(2)$ dimana parameternya sebesar $\quad-0,788$ artinya: peluang partisipasi wanita berwirausaha yang berpendidikan tinggi lebih rendah lagi dengan nilai Exp (B) sebesar 0,455 dan dapat diartikan peluang wanita berpendidikan tinggi untuk berwirausaha hanya 0,455 kali bila dibandingkan peluang wanita yang berpendidikan rendah dan menengah. Dengan kata lain wanita di Sumatera Barat yang berpendidikan rendah yaitu SD kebawah - SD dan menengah memiliki kecenderungan yang lebih besar untuk berwirausaha bila dibandingkan yang berpendidikan tinggi.

\section{Jumlah Jam Kerja}


Hasil analisis untuk data Susenas 2019 jumlah jam kerja wanita yang lebih dari 34 jam parameternya yaitu sebesar 0,062 artinya: partisipasi wanita berwirausaha sendiri yang jumlah jam kerjanya lebih dari 34 jam maka peluangnya lebih besar dengan nilai Exp (B) sebesar 1,064 dapat diartikan peluang wanita berwirausaha sendiri yang jumlah jam kerjanya lebih dari 34 jam hanya 1,064 kali lebih besar bila dibandingkan peluang wanita yang jumlah jam kerjanya kurang dari 34 jam.

Usia

Pada variable age(1) parameter -0,493 artinya: peluang partisipasi wanita berwirausaha sendiri yang berusia kurang dari 30 tahun lebih kecil dengan nilai Exp (B) sebesar 0,611 dapat diartikan peluang wanita yang berusia kurang dari 30 tahun untuk berwirausaha sendiri 0,611 kali lebih kecil bila dibandingkan peluang wanita yang berusia lebih dari 30 tahun.

Begitu juga terlihat pada variable age(2) dimana parameternya sebesar 0,095 artinya: peluang partisipasi wanita berwirausaha sendiri yang berusia 40 tahun sampai lebih dari 40 tahun lebih besar dengan nilai Exp (B) sebesar 1,100 dan dapat diartikan peluang wanita yang berusia 40 tahun sampai lebih dari 40 tahun untuk berwirausaha sendiri 1,100 kali lebih besar bila dibandingkan peluang wanita yang berusia kurang dari 30 tahun.

\section{Persamaan Regresi Berganda (Multiple Regression).}

Hasil estimasi Regresi Berganda Faktor-faktor Suksesnya Wirausaha Wanita di Sumatera Barat 2019 (Data Susenas 2019), dapat kita lihat pada table berikut ini:

\section{Tabel 3}

Faktor-faktor Suksesnya Wirausaha Wanita di Sumatera Barat 2019

\begin{tabular}{|c|c|c|c|c|c|}
\hline Variable & Status Perkawinan & Pengalaman & TIK 1 (Telepon) & TIK 2 (Internet) & Const \\
\hline $\mathbf{B}$ & 0.074 & -0.001 & -0.054 & 0.656 & 7.063 \\
\hline Sign & $0.014^{*}$ & $0.009^{*}$ & $0.041^{*}$ & $0.000^{*}$ & 0.000 \\
\hline * Signifikan secara statistika pada level 5\% & \multicolumn{3}{l|}{} \\
\hline $\mathbf{n}=\mathbf{5 1 9 2}$ & F-Test $=\mathbf{1 7 . 5 6 2}$ & (Sign F-Test 0.000) \\
\hline
\end{tabular}

Sumber : diolah dari Raw data Susenas 2019

$\mathrm{Y}=7.063+0.074$ Stat $(\mathrm{X} 1)-0.001 \operatorname{Exp}(\mathrm{X} 2)-0.054$ TIK1 (X3) + $0.656 \mathrm{TIK} 2(\mathrm{X} 4)$

Variabel status perkawinan dan penggunaan Internet signifikan dan positif mempengaruhi suksesnya wanita dalam berwirausaha di Sumatera Barat. Hasil ini sesuai dengan penelitian sebelumnya yang dilakukan oleh Coates (1988), dan Millman dan Hartwick (1987) dalam Syed (2019) dimana umumnya menunjukkan bahwa Teknologi Informasi dan Komunikasi (TIK) memiliki dampak yang besar terhadap produktivitas bisnis. Sedangkan variabel pengalaman dan penggunaan telepon signifikan akan tetapi bernilai negatif, dimana hal ini mungkin saja terjadi karena semakin berpengalamannya seseorang maka ketakutan untuk menerima resiko kegagalan dalam berwirausaha semakin tinggi. Kemudian untuk penggunaan telepon keadaan ini bisa saja terjadi karena penggunaan internet lebih banyak menjadi media komunikasi seperti penggunaan aplikasi seperti Whatsaap, Telegram dan lainlain. 


\section{Kesimpulan}

Berdasarkan hasil temuan empiris seperti yang telah diuraikan maka dapat diambil kesimpulan bahwa, wirausaha wanita di Sumatera Barat di derah perkotaan lebih berpeluang untuk berwirausaha, dengan tingkat pendidikan masih rendah (SD Kebawah), dan status perkawinan menikah atau bercerai (baik cerai hidup atau mati), dengan usia 40 tahun keatas lebih berpeluang untuk ikut berwirausaha. Banyaknya jumlah tanggungan 1 - 4 orang lebih berpeluang untuk berwirausaha bila dibandingkan dengan yang memiliki jumlah tanggungan lebih dari 4 orang, dengan jumlah jam kerjanya lebih dari 34 jam, dari uraian diatas mengindikasikan bahwa kebanyakan wanita di Sumatera Barat menjadi wirausaha terutama disebabkan oleh faktor pendorong yaitu push factor, dimana tekanan ekonomi dan demi memenuhi kebutuhan rumah tangga menjadi dorongan bagi wanita untuk ikut berpartisipasi dalam berwirausaha. Faktor-faktor yang mempengaruhi suksesnya seorang wanita dalam berwirausaha di Sumatera Barat yaitu disebabkan oleh status perkawinan, penggunaan internet, pengalaman dan penggunaan telepon.

\section{Daftar Pustaka}

Adeyemi, The characteristics of succesful nigerian women entrepreneurs, Department of business administration, University of Ilorin.

Amalia, Euis Sei MM. Bukan Lagi Pencari Nafkah Tambahan, Bacaan Utama Wanita Islam Bulanan Paras. No. 29 Februari 2006.

Amalia, Reni. (2011). Analisis Faktor-faktor yang Mempengaruhi Pekerja Untuk Berwirausaha di Kota Pekanbaru (Analisis Pendekatan Etnis). Program Studi Perencanaan Pembangunan. Pasca Sarjana. Universitas Andalas. Padang

Alam, Mohd Jani, Omar, An Empirical Study of Success Factors of Women Entrepreneurs in Southern Region in Malaysia, International Journal of Economics and Finance, www.ccsenet.org/ijef, Vol. 3, No. 2; May 2011.

B. M. Staw. (1991). Psychological Dimensions of Organizational Behaviour. MacMillan Publishing Company. Sdney.

Bygrave, W. D. (2004). The Portabel MBA in Entrepreneurship. Third Edition, edited by William D. Bygrave, Andrew Zacharakis. - Ed. 3 - New Jersey: John Willey \& Sons Inc.

Carree, M. A. and R. Thurik. (2003). The Impact of Entrepreneurship on Economic Growth. Handbook of Entrepreneurship Research, Boston/Dordrecht: Kluwer-Academic Publishers, pp. 437-471.

Coates, V. T. (1988). Office automation: Productivity, employment and social impacts. Office: Technology and People, 3: 315-326.

Cipolla, C. M. (1981). Before the Industrial Revolution: European Society and Economy. 2nd Edition, Cambridge, UK: Cambridge University Press. 
Davidsson, P. (2003). The Domain of Entrepreneurship Research: Some Suggestions. in Jerome A. Katz and Dean Shepherd (eds.), Cognitive Approaches to Entrepreneurship Research, Advances in Entrepreneurship, Firm Emergence and Growth 6, pp. 315-372.

Diah, Windarti. Determinants of Labour Force Participation by Married Women, The Case of Jakarta . Bulletin of Indonesia Economics Studies 2 Augustus 1998. Volume: 34.

Dewi A, Yunita. (2009). Analisis Faktor - faktor Yang Mempengaruhi Lulusan SMK Dalam Berwirausaha di Sumatera Barat. Pasca Sarjana Universitas Andalas, Padang.

Djalal, Nachrowi. Hardianus, Usman. (2002). Penggunaan Teknik Ekonometrik. Rajawali Press. Jakarta.

Djamal, Chamsiah. (1991). Perempuan Indonesia: dulu dan kini. Dalam kajian Membantu Suami Mengurus Rumah Tangga: Perempuan di Sektor Informal.

Dockhak, Latief. (1986). Pekerjaan Wanita Berkeluarga yang Menunjang Keutuhan Peranannya. Makalah Pada Simposium Tentang Wanita, Kerja dan Keutuhan Peranannya. Hal: 110. Yogyakarta.

Elfindri, B. Nasri. Ekonomi Ketenagakerjaan. Andalas University Press. Hal: 42, 2004.

Elfindri, Nazer. M, Lindawati, B. Nasri. Aplikasi Analisis Pasar Kerja: Kenyataan Untuk Wanita Kawin. Jurnal Ekonomi dan Manajemen Fakultas Ekonomi Universitas Andalas. Hal: 85 - 86, 2003.

F. Glueck, William. Business Policy dan Strategic Management. Auckland: McGraw-Hill International Book Company. Hal: 46, 1982

Germaine Ibro, Joan Fulton Professor, James Lowenberg-DeBoer Professor, Factors affecting success for women entrepreneurs in west africa: The case of kossai, a value added cowpea product. selected paper prepared for presentation at 2006 american agricultural economics Association annual meeting, long beach, california, July 23-26, 2006.

Gilad, B and Levine. P. (1986). A Behaviour Model of Entrepreneurial Supply. Journal of Small Business Management, 24.

Handy Femida, Kassam Meenaz, Ranade Shree. (2003). Factors Influencing Women Entrepreneurs of $N G O s$ in India, University of Pennsylvania.

Ibro, Germaine. Fulton, Joan. James, Lowenberg-DeBoer. (2006). Factors Affecting Success for Women Entrepreneurs in West Africa: The Case of Kossai, a Value Added Cowpea Product. Selected Paper prepared for presentation at American Agricultural Economics Association Annual Meeting, Long Beach, California, July 23-26, 2006.

I. Sedijoprapto, Endang. (1982). Tenaga Kerja Wanita Indonesia, Suatu Tinjauan Literatur. LIPI. Jakarta.

International Center for Research on Women (ICRW). Cherie Blair Foundation For Women. (2012). How Mobile Phones, Computers and The Internet Can Catalyze women's Entrepreneurship, India: A Case Study. ICRW Report. 
Iwantono. S. (2002). Kiat Sukses Berkewirausahaan. Jakarta. Grasindo.

Izedonmi, Famous and Chinonye, Okafor. (2007). Assesement of The Entrepreneurial Characteristics and Intentions Among Academics.

Jovanovic, B. (1994). Entrepreneurial Choice When People Differ in their Management and Labor Skills. Small Business Economics 6(3), 185-192.

Kementerian Koperasi dan Usaha Kecil dan Menengah Republik Indonesia. (2011). Kebangkitan Koperasi dan UMKM Menuju Kesejahteraan Rakyat. Laporan Kinerja Kementerian Koperasi dan Usaha Kecil dan Menengah Republik Indonesia.

Kirzner, I. M. (1973). Competition and Entrepreneurship. Chicago: University of Chicago Press.

Khairuza, Miftah. (2011). Pengaruh tingkat partisipasi perempuan dalam Usaha ekonomi mikro terhadap tingkat sosial Ekonomi keluarga di kelurahan harjosari ii kecamatan medan amplas kota medan.

Latief, Abdul. (1993). Membangun SDM yang Mandiri dan Profesional. Departement Tenaga Kerja Republik Indonesia.

Mahmuddin. (2010). Faktor-faktor Pendorong Kewirausahaan.

Makhbul, Zafir Mohd, dan Hasun, Fazilah Mohamad. January (2011). Entrepreneurial Success: An Exploratory Study among Entrepreneurs. International Journal of Business and Management Vol. 6, No. 1; 2011. www.ccsenet.org/ijbm

McClelland, D.C. 1961. The Achieving Society. D. Van Nostrand. Place of Publication: Princeton, NJ. Publication.

Miko, Alfian. Profil Wanita Anak Jahit di Industri Konveksi Sungai Puar Kabupaten Agam. Pusat Penelitian Universitas Andalas. Padang. Hal 2-17. 1997.

Millman, Z. and Hartwick, J. (1987). The Impact of Automated Office Systems on Middle Managers and Their Work. MIS Quarterly, 11(4): 479-492.

Mizgajska Hanna, Factors Influencing Women Entrepreneurship In Regions Of Low Professional Activity On The Example Of Poland, Poznań University of Economics, Poland.

Nurul Indarti, Marja Langenberg, Factors affecting business success among smes: Empirical evidences from Indonesia, Gadjah mada university.

Nour Mohammad Yaghoubi, Faezeh Ahmadi, Factors Affecting the Women Entrepreneurship in Industrial Section. European Journal of Social Sciences, Volume 17, Number 1. 2010.

Oey, Mayling. (1989). Dari Rumah Tangga ke Pasar. Harian Kompas.

Olasanmi, Omoneye. Ayoola Tajudeen j. Kareem-ojo Mutiat. (2012). Evaluation of ICT use Among Women Entrepreneurs in the Nigerian Garment Industry. International Journal of Management \& Business Studies. IJMBS Vol. 2, Iss ue 1, Jan. - March 2012. ISSN : 2230-9519 (Online)| ISSN : 2231-2463 (Print).

Prihatin Dwi Riyanti, B. (2004). Factors influencing the success of small-scale entrepreneurs in Indonesia. Atmajaya Catholic University, Jakarta, Indonesia. 
Pujiwati, Sajogyo. (1983). Peranan Wanita Dalam Perkembangan Masyarakat Desa. CV. Rajawali. Jakarta. Hal: 113

Rachbini, Dj. (1993). Ekonomi Informal Perkotaan.

Raduan, R., Naresh, K., \& Lim, L. Y. (2006). Entrepreneur"s success factors and escalation of small and medium-sized enterprises in Malaysia. Journal of Social Sciences, 2(3), 74-80.

Sari, Indah Maya. (2007). Partisipasi Wanita Dalam Berwirausaha di Sumatera Barat. Fakultas Ekonomi. Universitas Andalas. Padang

Segal, Gerry. Borgia, and Jerry, Schoenfeld. (2005). The Motivation to Become an Entrepreneur. International Journal of Entrepreneurial Behaviour and Research. Vol. 11 No. 1, PP 44-57

Sriyani Wasantha. (2010). Factors affecting the success of micro level women entrepreneurs in southern province in Sri Lanka, Department of Management and Entrepreneurship, Faculty of Management and Finance, University of Ruhuna, Matara, Sri Lanka.

Stevenson. H. Howard. (2000). Why Entrepreneurship Has Won!. USASBE Pleanry Addres Harvard University. Coleman White Paper.

Supriadi. (2009). Konsepsi dan Aktualisasi Kebijakan Untuk Pemberdayaan Ekonomi Kerakyatan Bagi Perempuan dan Bangsa Indonesia Dalam Menghadapi Globalisasi.

Suryanto, dan Hendarso. Pemberdayaan dan Kesetaraan Perempuan. Prisma.

5 Mei 1996.

Suryana. (2006). Kewirausahaan pedoman praktis: Kiat dan Proses Menuju Sukses. Salemba Empat.

Tan Firwan. (2007). Ekonomi Rakyat dan Mewirausahakan Masyarakat. Padang Diktat Pendampingan Sosial Fakir Miskin. BBPPKS.

Tambunan Tulus. (2012). Wanita Pengusaha di UMKM di Indonesia: Motivasi dan Kendala. Policy Discussion Paper Serie. Center For Industry, SME \& Bussiness Competition Studies. Trisakti University.

Tuladhar Iyoti, Factor Affecting Women Entrepreneurship in Small and Cottage Industries in Nepal Opportunities and constraints, September, 1996.

United Nations Economic Commission For Europe (2004). Series: Entrepreneurship And SMEs Access To Financing and ICT For Women Entrepreneurs In The UNECE Region. Challenges And Good Practices. Geneva And New York.

Wardatulaina, Siti Nur M.Y. (2011). Success Factors in Entrepreneurship: The Case of Malaysia. Departament d'economia de l'empresa. European doctoral programme in Entrepreneurship and small business management.

Weiss, L. W. (1976). Optimal Plant Scale and the Extent of Suboptimal Capacity. in R. T. Masson and P. David Qualls (eds.), Essays on Industrial Organization in Honor of Joe S. Bain, Cambridge, Mass: Ballinger. 
Wennekers, S. and R. Thurik. (1999). Linking Entrepreneurship and Economic Growth. Small Business Economics 13(1), 27-55. 